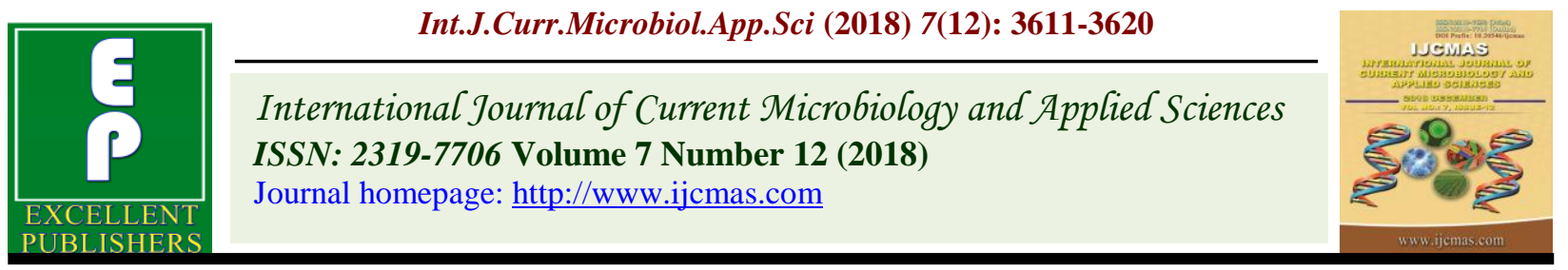

Original Research Article

https://doi.org/10.20546/ijcmas.2018.712.409

\title{
Report of Novel Entomopathogenic Nematode (Heterorhab ditidoides sp.) in Telangana state, India
}

\author{
Amit. U. Paschapur ${ }^{1 *}$, K. Vijaya Lakshmi ${ }^{2}$, Khushbu Chauhan ${ }^{3}$, B. S. Sunanda ${ }^{2}$, Chetna \\ Mathur $^{3}$, Chaitra Bhat ${ }^{3}$, Vishal Somavanshi ${ }^{3}$, Uma Rao $^{3}$ and Vinod Pawar ${ }^{2}$ \\ ${ }^{1}$ Division of Entomology, ${ }^{3}$ Division of Nematology, ICAR-IARI, New Delhi- 110012, India \\ ${ }^{2}$ National Institute of Plant Health Management, Rajendranagar, Hyderabad-500030, India \\ *Corresponding author
}

\section{A B S T R A C T}

\begin{tabular}{|l|}
\hline Ke y w o r d s \\
Soil survey, \\
Telangana state, \\
Molecular \\
characterization, \\
Heterorhabditidoid
\end{tabular}

\section{Introduction}

Entomopathogenic nematodes are soft bodied, non-segmented roundworms that are obligate or sometimes facultative parasites of insects. Entomopathogenic nematodes are widely distributed throughout the world and have wide range of insect hosts (Hominick, 2002). Introduction of EPNs as biological control agents in a particular site requires prior knowledge on their occurrence and proper identification of native species. Introduction of exotic EPNs may induce exclusion of the local populations and/or species, thus eroding
A soil survey was carried out during 2016-2017 in four predominantly Sugarcane growing districts of Telangana state, viz., Sangareddy, Kamareddy, Nizamabad and Khammam, for the presence of entomopathogenic nematodes (EPNs) from Sugarcane ecosystem. The soil samples collected from Kamareddy district showed the highest occurrence of EPNs in $33.33 \%$ of the soil samples, followed by Sangareddy $(23.33 \%)$, Khammam $(16.67 \%)$ and Nizamabad $(5.55 \%)$ districts. The isolates of EPNs were utilized for molecular characterization and identification. The genomic DNA of EPN isolates was extracted and $18 \mathrm{~S}$ and 28S ITS rDNA region of genomic DNA was amplified by PCR technique using a molecular studies shown the occurrence of Heterorhabditis indica in $41.18 \%$ of the soil samples, followed by Heterorhabditidoides sp. in $23.53 \%$ and $H$. $H$. indica was dominant EPN species occurring in Sugarcane ecosystem. The new EPN species Heterorhabditidoides spp. was reported for the first time in India. 
of native entomopathogenic nematodes in the field level are necessary for successful control of endemic pests in a particular location without causing any imbalance in biodiversity of the locality. With this basic knowledge, a soil survey was conducted during 2016-2017 in four predominantly Sugarcane growing districts of Telangana state, viz., Sangareddy, Kamareddy, Nizamabad and Khammam, for the presence of entomopathogenic nematodes (EPNs) from Sugarcane ecosystem. Once the EPNs are isolated from soil, accurate identification is fundamental to understand the geographical distribution and habitat specificity of entomopathogenic nematodes. The distinctions based on molecular characterization will elucidate species and groupings, which can then be studied for morphological characters that distinguish them from each other.

The Internal Transcribed Spacer region (ITS), located between the repeating array of nuclear $18 \mathrm{~S}$ and $28 \mathrm{~S}$ ribosomal DNA genes, is a versatile genetic marker, among eukaryotes, including organisms as diverse as protozoa, plants, vertebrates, nematodes and fungi. ITS data have been used in constructing phylogenetic trees, estimating genetic population structures, evaluating population level evolutionary processes, and determining taxonomic identity. The application of the ITS region for identification of nematodes has received the most attention by nematologists (Campbell et al., 1995; Cherry et al., 1997; Joyce et al., 1994; Vrain and McNamara, 1994). The majority of these studies have focussed upon agriculturally important plantparasitic species, animal parasites, or beneficial insect parasites. Yet, there is not a single nematode species that has failed to provide an amplification product of the ITS region when amplified with "Universal" PCR primer sets. Universal amplification coupled with the ability to amplify ITS from individual nematodes suggests that any species, population, or ecological community of nematodes can be analyzed using a molecular approach based on the rDNA ITS region (Vrain and McNamara, 1994).

\section{Materials and Methods}

For identification of isolated EPNs, molecular characterization studies were carried out. DNA was extracted using the DNA extraction method developed by Holterman et al., (2006) and DNA was purified using a protocol of Purelink® genomic DNA mini Kit (Fig. 1).

Genomic DNA from nematodes was extracted and PCR amplification of nematode ITS rDNA region using universal primers was carried out. Universal primers used for amplification of ITS rDNA region was SC356 (primer code) designed by Vrain et al., (1992).

Forward primer: TTGATTACGTCCCTGCC CTTT

Reverse primer: TTTCACTCGCCGTTAC TAAGG

Product size: $1000-1100$ bp

Once the ITS rDNA region was amplified by PCR, the PCR (polymerase chain reactions), products were sent for sequencing to AgriGenome laboratories private limited, Kochi, Kerala. Nucleotide BLAST (Basic Local Alignment Search Tool) of the sequenced samples was performed using NCBI database programme BLASTN 2.6.1+ (Fig. 2, 3 and 4).

\section{Results and Discussion}

In the soil survey, out of 90 soil samples collected from four districts of Telangana state for studying the prevalence of EPNs using bating technique, 17 isolates tested positive for EPNs, which constituted $18.89 \%$ recovery. These isolates were subjected to molecular characterization studies to identify the 
different species of EPNs and the results obtained from the studies are presented in the table 1 and figure 4.

The 17 isolates which showed positive reaction for EPNs were subjected to molecular characterization and identification of the EPNs was done by amplifying the ITS region found between the $18 \mathrm{~S}$ and $28 \mathrm{~S}$ rDNA using universal primer SC356 (primer code) designed by Vrain et al., (1992). Based on universal primer, the amplification of $18 \mathrm{~S}$ and $28 \mathrm{~S}$ rDNA genomic region confirmed that, out of 17 isolates, 14 isolates were EPNs belonging to order Rhabditida and the genomic DNA of three isolates did not amplify, indicating them as nematodes belonging to the orders other than Rhabditida. These results were recorded based on the presence of PCR amplified ITS region of DNA found between the 18S and 28S rDNA by visualizing the DNA bands obtained on the Agarose gel cube under UV light with an Alpha Imager EP Gel documentation system and banding pattern (Plate 1).

Based on molecular characterization and nucleotide BLAST results, three species of EPNs were identified in the soil samples. They were Heterorhabditis indica, Heterorhabditis bacteriophora and Heterorhabditidoides sp. Among the three species, $H$. indica was the dominant species comprising $41.18 \%$ of the total population, followed by Heterorhabditidoides sp. (23.53\%) and $H$. bacteriophora comprising $17.65 \%$. Among the three species, the occurrence of Heterorhabditidoides sp. was reported for the first time in India.

The occurrence of different species of EPNs from four districts of Telangana state indicated that, in Sangareddy, out of the seven samples tested positive for EPNs, five samples had $H$. indica and two samples recorded the presence of $H$. bacteriophora. In Kamareddy out of four samples tested positive for EPNs, the molecular analysis results indicated the existence of $H$. indica in two samples, and Heterorhabditidoides sp. in one sample. While in one sample the nematode identification was not confirmed. In Nizamabad district one sample which tested positive for EPNs was found to be Heterorhabditidoides sp. In Khammam among the five samples which gave the positive results for EPNs, two samples belong to Heterorhabditidoides sp., one sample was $H$. bacteriophora, while two samples did not reveal the presence of EPN species.

Thus the results obtained from the molecular analysis studies clearly revealed the presence of two genera of EPNs, viz., Heterorhabditis and Heterorhabditidoides. Among the Heteorhabditid genera, two species were recorded, viz., $H$. indica and $H$. bacteriophora. In the present study new EPN belonging to the new genus Heterorhabditidoides was identified for the first time in India. This nematode has provided evidence for its being entomopathogenic, as it killed G. mellonella quickly and efficiently. Existence of this nematode genus Heterorhabditidoides was reported from China by Zhang et al., (2008 and 2012) based on morphological characters combined with molecular data. In the present study the occurrence of $H$. indica in Sugarcane field supports the findings made by Poinar (1983) who documented the prevalence of $H$. indica from sugarcane fields at Coimbatore.

The $H$. indica species has been commonly isolated from sub-tropical and tropical regions of the world such as Srilanka (Amarasinghe et al., 1994), Cuba (Joyce et al., 1994) and Egypt (Shamseldean and Abd-Elgaw, 1994). In India the species has been reported to occur in Coimbatore and Kanyakumari districts (Ambika, 1995), Kerala (Gulsar et al., 2004), Bangalore (Hussaini et al., 2000) and 
Telangana state (Sunanda et al., 2016). The prevalence of $H$. bacteriophora was recorded from Czech republic (Mracek et al., 2008). Singh et al., (2015) reported the occurrence of $H$. bacteriophora and $H$. indica from cultivated fields, forests and garden soils of Gorakhpur divisions of India.

In the present study, the documentation of the prevalence of $H$. indica in greater proportions and identification of a novel EPN species
Heterorhabditidoides sp., in Sugarcane fields of Telangana state has paved the path for further exploitation of these species in biological control of Sugarcane root grubs. The future studies on identification of symbiotic bacteria associated with Heterorhabditidoides sp. can also provide valuable information regarding the use of this novel genus for the management of Sugarcane root grubs (Fig. 5).

Table.1 Occurrence of different species of entomopathogenic nematodes from Sugarcane growing districts of Telangana state

\begin{tabular}{|c|c|c|c|c|c|}
\hline $\begin{array}{l}\text { Sl. } \\
\text { no. }\end{array}$ & $\begin{array}{l}\text { District } \\
\text { surveyed }\end{array}$ & $\begin{array}{l}\text { Samples } \\
\text { tested } \\
\text { positive } \\
\text { for EPNs }\end{array}$ & $\begin{array}{l}\text { Major EPN species } \\
\text { identified }\end{array}$ & $\begin{array}{l}\text { Samples } \\
\text { tested } \\
\text { positive for } \\
\text { different } \\
\text { EPN } \\
\text { species }\end{array}$ & $\begin{array}{l}\text { Samples } \\
\text { tested } \\
\text { positive for } \\
\text { different } \\
\text { species } \\
(\%)\end{array}$ \\
\hline \multirow[t]{2}{*}{1.} & \multirow[t]{2}{*}{ Sangareddy } & \multirow[t]{2}{*}{7} & H. indica & 5 & 71.43 \\
\hline & & & H. bacteriophora & 2 & 28.57 \\
\hline \multirow[t]{3}{*}{2.} & \multirow[t]{3}{*}{ Kamareddy } & \multirow{3}{*}{4} & H. indica & 2 & 50.00 \\
\hline & & & Heterorhabditidoides sp. & 1 & 25.00 \\
\hline & & & Not confirmed & 1 & 25.00 \\
\hline 3. & Nizamabad & 1 & Heterorhabditidoides sp. & 1 & 100.00 \\
\hline \multirow[t]{3}{*}{4} & \multirow[t]{3}{*}{ Khammam } & \multirow{3}{*}{5} & H. bacteriophora & 1 & 20.00 \\
\hline & & & Heterorhabditidoides sp. & 2 & 40.00 \\
\hline & & & Not confirmed & 2 & 40.00 \\
\hline & \multirow{4}{*}{$\begin{array}{l}\text { Total } \\
\text { samples }\end{array}$} & \multirow{4}{*}{17} & H. indica & 7 & 41.17 \\
\hline & & & H. bacteriophora & 3 & 17.64 \\
\hline & & & Heterorhabditidoides sp. & 4 & 23.52 \\
\hline & & & Not confirmed & 3 & 17.64 \\
\hline
\end{tabular}


Fig.1 Procedure for extraction of genomic DNA from EPNs

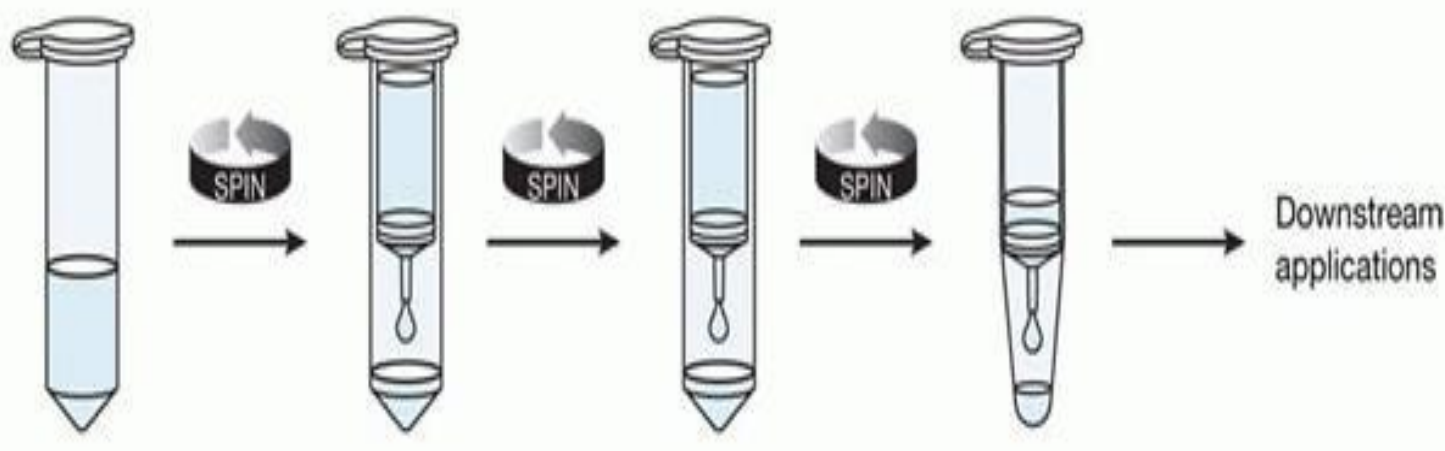

Sample preparation DNA Winding Elution

and pretreatment

Fig.2 Trimmed sequence (879 bp) of Heterorhabditidoides sp.

TGCTTAAGTTCGGCGGGTAATCACGACTGAGCTCAGGTTGCTAAGACAAGGCGC AAGCTCAGAACGGCATCATAAGCGACCGAAGGCTACTCAACCAGAAGCAGCGGT AGAGAGCCGACGGCAATGCACGTTCGACGAGCACACCTACAGCGAGACTAGAA GTCTCATGTTGCTTTCATTCTTTACTAGAACGAGTACGCTTGCGCATAGTCGCTCG ACAAGCCAACGCCGAAGCGATGGCAGTTAAGAAAACAACCCTGAACCAGACGT GCCGACGGGAAAAACCCGACGGCGCTGTGCGTTCCAAATTTCACCACTCAAAGC GTCTGCAATTCGTGGTAAATAACGGAGCTAGCTCCGTTGTTCATCGATATGCGAA TCGACCGATCCATCCCAATGGGTAGTAAGAGTATGTTCTTTCGAACAAGCCAAAA CATAAGTTAAGTAAAAGGAAAGGGGGTTTGCCGCCCACGTTCTCTTCCACGAAA GAAGAGCAACGCAAGTCATTAAGGCTTCCACCGCCAATGGATGGTAATATAGCC AGCAAGGGAAACATTGCGAGGCGGTAGCCATAGCTGCTACACTTTACGTTCGCC GAACCACTGCACACTGAAGCGCGCTGTGGAATCAGACTGTTGCGCCCGAGTCCG AAAACCCAGATGCTGCGGTCGCATAAAGCCGCCAGACTGATGAACGAACACCTC ACGTTATGCTGCACGTGGCAAGTATCGGAAGGAGACAGACCAAAAGCCCGTTCC CATTTGCGACCGACACTCAACCGTATCAAAGCCAGAGTTCCGTTAGGAATCAGC GATGATCCACCTGCAGGTTCACCTACAGGTACCTTGTTACGACTTTTGCCCGGTT CAAGCCATTGCG 
Fig.3 Nucleotide BLAST (Basic Local Alignment Search Tool) of the sequenced samples

\section{BLAST Results}

Job title: AH11_VS3.F_1668-21_P0199,Trimmed Sequence(832...

RID HRP94ZMC013 (Expires on 05-18 13:01 pm)

Query ID Icl|Query_216187

Description AH11_VS3.F_1668-21_P0199,Trimmed Sequence(832 bp)

Database Name $\mathrm{nr}$

Description Nucleotide collection (nt)

Molecule type nucleic acid

Program BLASTN 2.6.1+

Query Length 832

\section{Graphic Summary}

Distribution of the top 105 Blast Hits on 100 subject sequences

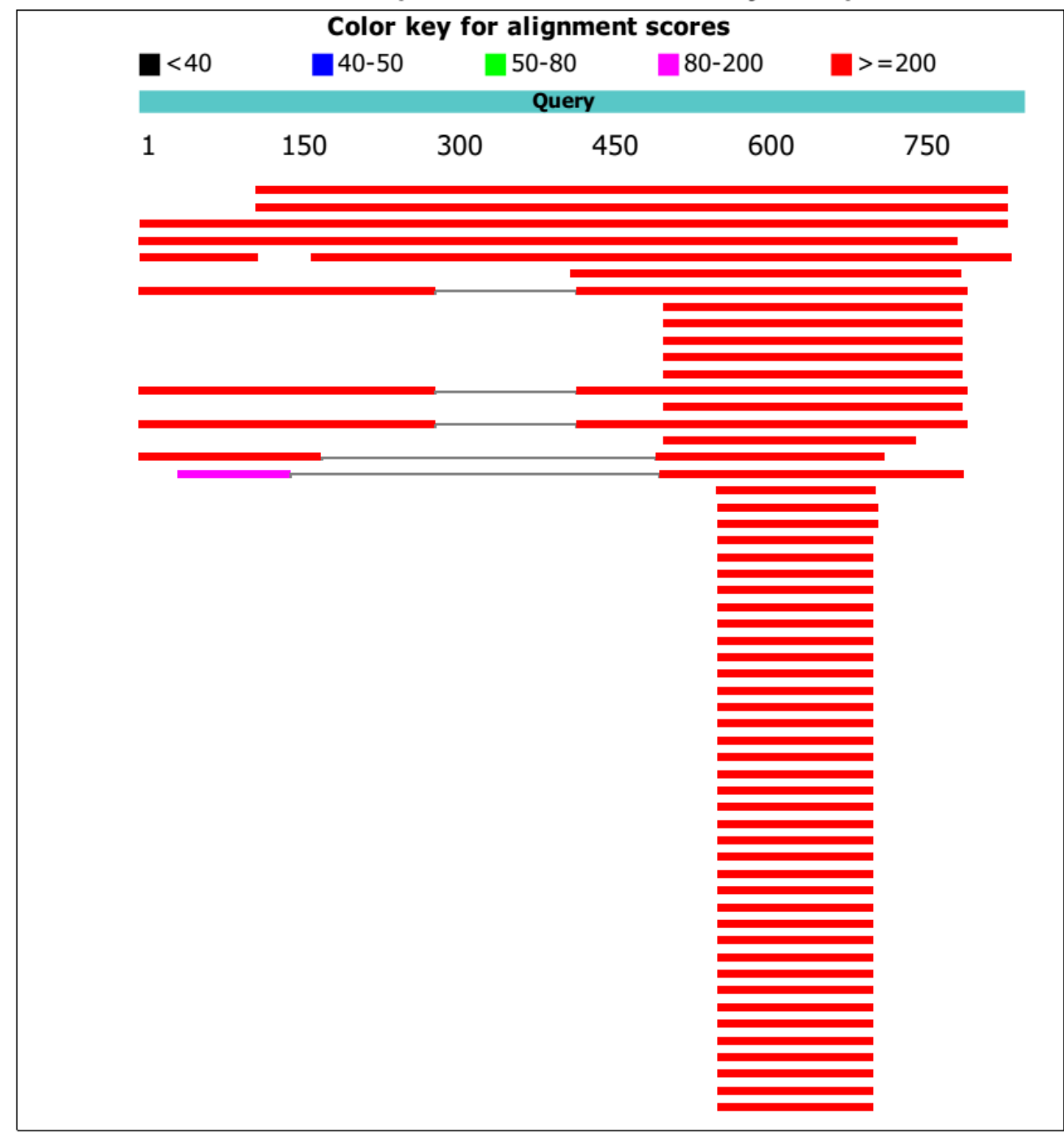


Fig.4 The new sequences showing 99\% resemblance to Heterorhabditidoides sp.

\section{Descriptions}

Sequences producing significant alignments:

\begin{tabular}{|c|c|c|c|c|c|c|}
\hline Description & $\begin{array}{l}\text { Max } \\
\text { score }\end{array}$ & $\begin{array}{l}\text { Total } \\
\text { score }\end{array}$ & $\begin{array}{l}\text { Query } \\
\text { cover }\end{array}$ & $\begin{array}{l}\mathrm{E} \\
\text { value }\end{array}$ & Ident & Accession \\
\hline $\begin{array}{l}\text { Heterorhabditidoides sp. BRA6 genomic } \\
\text { DNA sequence contains } 18 \mathrm{~S} \text { rRNA gene, } \\
\text { ITS1, } 5.8 \mathrm{~S} \text { rRNA gene, ITS2 and } 28 \text { S rRNA } \\
\text { gene, strain BRA6, clone BRA6_11 }\end{array}$ & 1293 & 1293 & $86 \%$ & 0.0 & $99 \%$ & LN611142.1 \\
\hline $\begin{array}{l}\text { Oscheius sp. MCB } 18 \mathrm{~S} \text { ribosomal RNA } \\
\text { gene, partial sequence; internal transcribed } \\
\text { spacer } 1,5.8 \mathrm{~S} \text { ribosomal RNA gene, and } \\
\text { internal transcribed spacer } 2 \text {, complete } \\
\text { sequence; and } 28 \mathrm{~S} \text { ribosomal RNA gene, } \\
\text { partial sequence }\end{array}$ & 1277 & 1277 & $86 \%$ & 0.0 & $99 \%$ & KF684370.1 \\
\hline
\end{tabular}

Fig.5 Occurrence of different species of entomopathogenic nematodes in the soil surveyed from Sugarcane growing districts of Telangana state

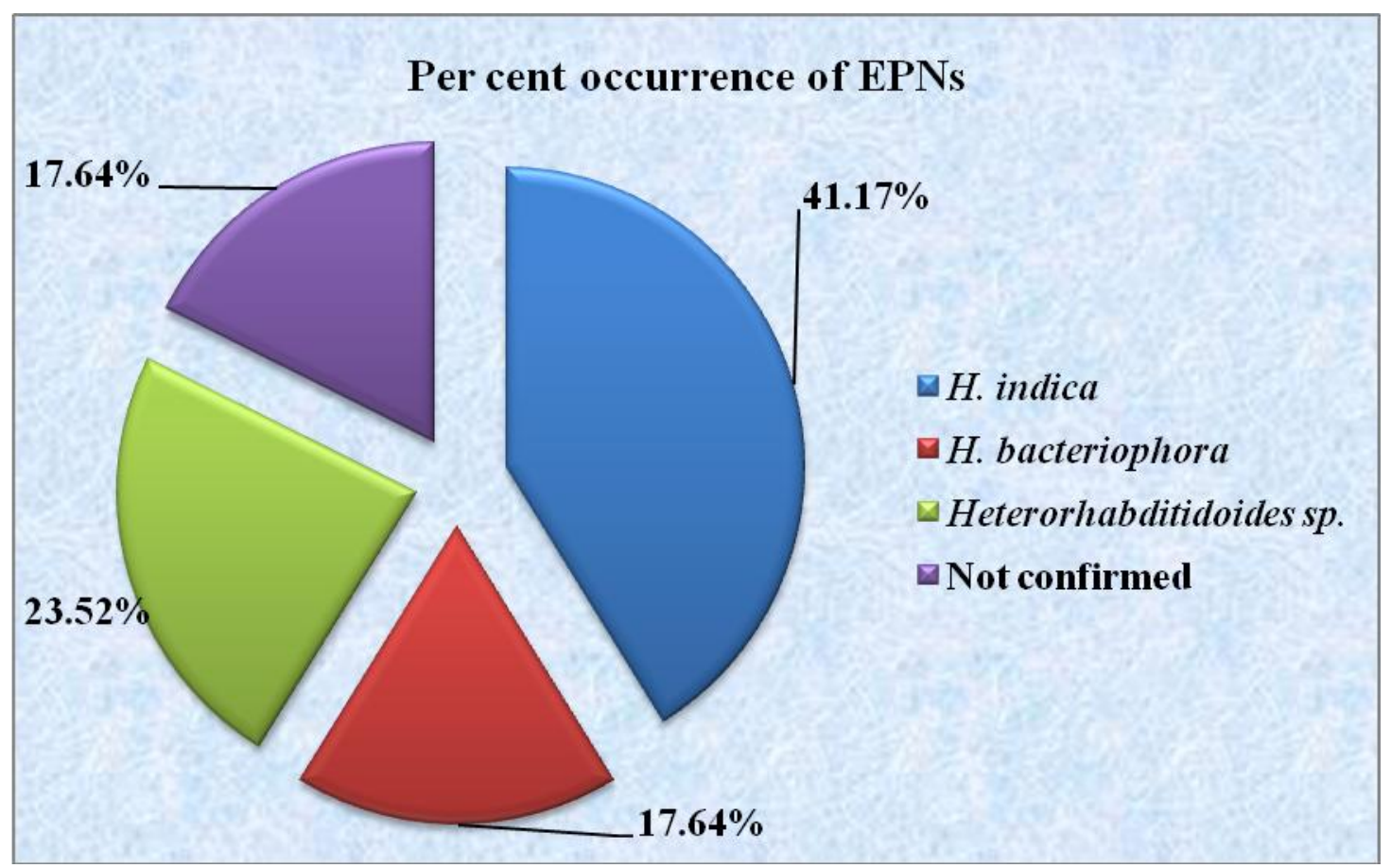


Plate.1 Bands of PCR amplified ITS region of DNA obtained on the agarose gel after electrophoresis

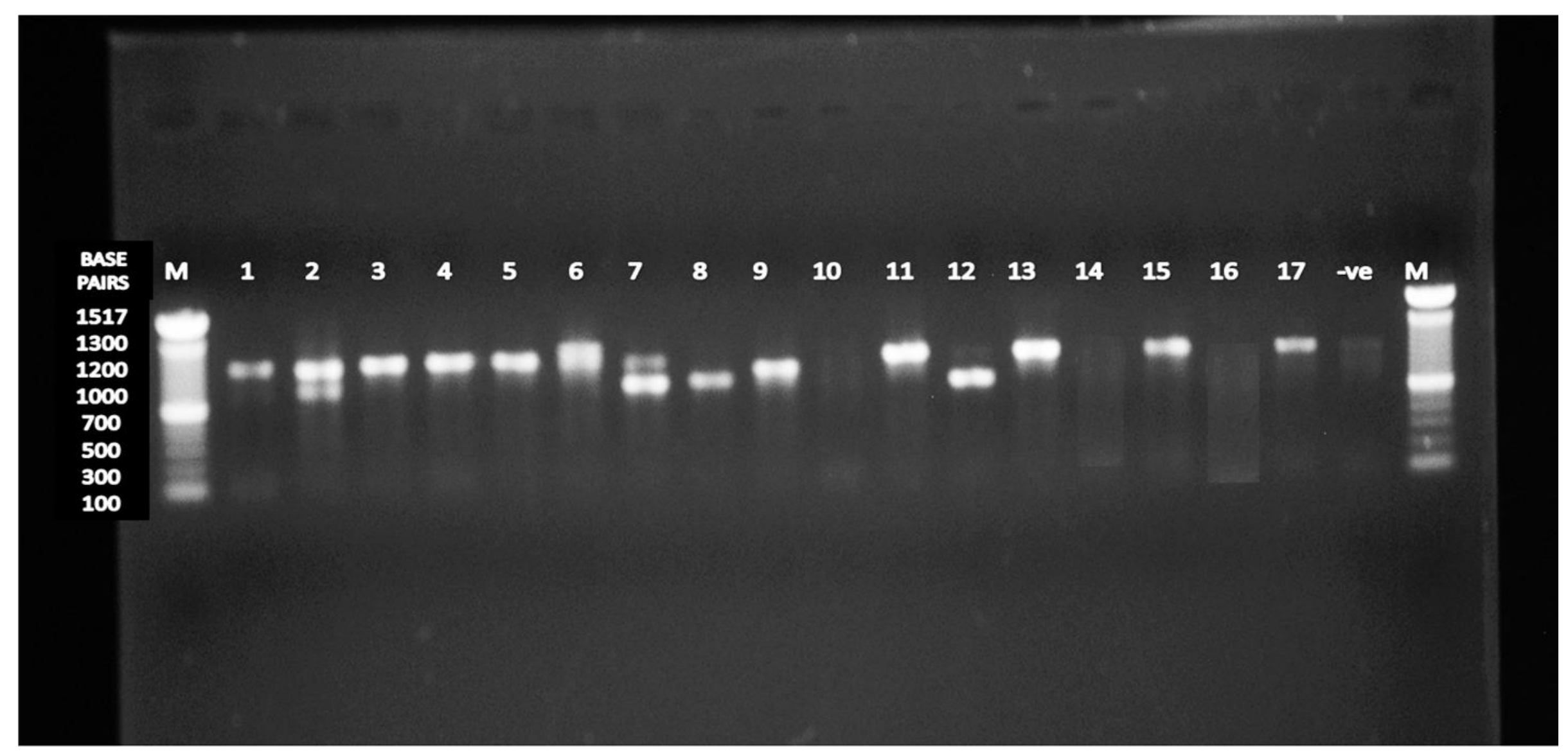

Note: Isolates 10, 14 and 16 did not form DNA bands when amplified using universal primer indicating that these isolates do not belong to order Rhabditida 
In conclusion, the present study constitutes the first report of Heterorhabditidoides sp. as one of the promising bioagents against Sugarcane root grubs in the Telangana state of India. The research findings made from the present study may open up the prospects of using Heterorhabditis and Heterorhabditidoides species in the biological control programme against Sugarcane root grubs. Future studies need to be carried out on the efficacy of the different species of entomopathogenic nematodes isolated from Telangana region for developing effective management strategies by choosing the right isolate suitable for their use in biological pest management of root grubs.

\section{Acknowledgement}

I am thankful to NIPHM for providing me assistance during soil survey and for conducting all the technical works at Nematology laboratory. I also owe my special gratitude to Division of Nematology, ICARIARI, New Delhi for providing me all the basic facilities to carry out molecular characterization of nematodes.

\section{References}

Amarasinghe, L.D., Hominick, W.M., Briscoe, B.R and Reid, A.P. 1994. Occurrence and distribution of entomopathogenic nematodes in Sri Lanka. Journal of Helminthology, 68: 277-286.

Ambika, V. 1995. Taxonomy, Distribution and Biology of Native Entomopathogenic Nematodes. Dissertation submitted for M. Sc. (Agri.) to the Tamil Nadu Agricultural University.

Campbell, A.J.D., R.B. Gasser and N.B. Chilton. 1995. Differences in a ribosomal DNA sequence of Strongylus species allow identification of single eggs. International Journal of Parasitology, 25: 359-365.

Cherry, T., A.L. Szalanski., T.C. Todd and T.O. Powers. 1997. The internal transcribed spacer region of Belonolaimus (Nemata: Belonolaimidae). Journal of Nematology. 29: 23-29.

Gulsar, B.J., Subahasan, K and Iyer, R. 2004. Occurrence and distribution of entomopathogenic nematodes in white grub endemic areas of Kerala. Journal of Plantation Crops, 32: 333-334.

Holterman, M., vander, W.A., Vanden, E.S., Van-Megen, H., Bongers, T., Holovachov, O., Bakker, J and Helder, J. 2006. Phylum-wide analysis of SSU rDNA reveals deep phylogenetic relationships among nematodes and accelerated evolution toward crown clades. Molecular Biology and Evolution 23: 1792-1800.

Hominick, W.M. 2002. Biogeography. In: Gaugler, R. (Ed.), Entomopathogenic Nematology. CABI Publishing UK, Wallingford, New York: 115-143.

Joyce, S.A., A.M. Burnell and T.O. Powers. 1994. Characterization of Heterorhabditis isolates by PCR amplification of segments of mtDNA and rDNA genes. Journal of Nematology, 26: 260-270.

Lacey, L.A. 2012. Manual of techniques in invertebrate pathology. Academic Press. London.

Miller, L.C and Barbercheck, M.E. 2001. Interaction between endemic and introduced entomopathogenic nematodes in conventional-till and notill corn. Biological Control. 22: 235245.

Mracek, Z., Stanislav, B., Pavel, K and Jana, J. 2005. Habitat preference for entomopathogenic nematodes, their insect hosts and new faunistic records for the Czech Republic. Biological 
Control. 34: 27-37

Hussaini, S.S., Ansari, M.A., Ahmad, W. and Subbotin, S.A. 2001. Identification of some Indian populations of Steinernema species (Nematoda) by RFLP analysis of ITS region of rDNA. International Journal of Nematology. 11:73-76.

Poinar, G.O.Jr. 1983. The Natural History of Nematodes. Prentice Hall, Englewood Cliffs.

Shamseldean, M.M and Abd-Elgawad, M.M. 1994. Natural occurrence of insect pathogenic nematodes (Rhabditida: Heterorhabditidae) in Egyptian soils. Afro-Asian Journal of Nematology, 4: 151-154.

Singh, S.P., Yadav, A., Vardhan, $\mathrm{S}$ and Tripathi, C.P.M. 2015. Diversity analysis of entomopathogenic nematodes against Helicoverpa armigera (Hübner) from Tarai region of IGP, India. Current Life Sciences. 1(1): $15-23$.

Sunanda, B.S., Jeyakumar, $\mathrm{P}$ and Vijayalakshmi, K. 2016. Diversity and distribution of entomopathogenic nematodes (EPNs) in different agro ecological habitats of Telangana State, India. The Ecoscan. 9: 67-71.
Vrain, T.C and D.G. McNamara. 1994. Potential for identification of quarantine nematodes by PCR. EPPO Bulletin. 24: 453-458.

Vrain, T.C., Wakarchuk, D.A., Lévesque, A.C., Hamilton, R.I. 1992. Intraspecific rDNA restriction fragment length polymorphism in the Xiphinema americanum group. Fundamental and Applied Nematology. 15 (6): 563-73.

Zhang, C., Liu, J., Xu, M., Sun, J., Yang, S., An, X., Gao, G., Lin, M., Lai, R., He, Z., Wu, Y and Zhang K. 2008. Heterorhabditidoides chongmingensis gen. nov., sp. nov. (Rhabditida: Rhabditidae), a novel member of the entomopathogenic nematodes. Journal of Invertebrate Pathology. 98(2): 153168.

Zhang, K. Y., Xiu, H., Liu, J. T., Ying, W., Lei, Q., Gabriel, Y., Chen, S., Dai, R., L, Qiu., Xiu, W. Y., Hao, W. T., Zhen, Y. S., Ren, L and Guo, F. G. 2012. Heterorhabditidoides rugaoensis n. sp. (Rhabditida: Rhabditidae), a novel highly pathogenic entomopathogenic nematode member of Rhabditidae. Journal of Nematology. 44(4): 348-360.

\section{How to cite this article:}

Amit. U. Paschapur, K. Vijaya Lakshmi, Khushbu Chauhan, B. S. Sunanda, Chetna Mathur, Chaitra Bhat, Vishal Somavanshi, Uma Rao and Vinod Pawar. 2018. Report of Novel Entomopathogenic Nematode (Heterorhabditidoides sp.) in Telangana state, India. Int.J.Curr.Microbiol.App.Sci. 7(12): 3611-3620. doi: https://doi.org/10.20546/ijcmas.2018.712.409 